\title{
Treatment of complex and "undilatable" coronary stenosis using rotational atherectomy with adjunctive or complementary balloon angioplasty
}

\author{
Teguh Santoso
}

\begin{abstract}
Abstrak
Diselidiki 32 penderita yang mempunyai kelainan pembuluh koroner kompleks dengan ciri-ciri morfologik dimana angioplasti koroner konvensional (PTCA) akan tidak memberi hasil baik, seperti stenosis ostial, lesi berkapur, lesi panjang dan difus, lesi restenotik atau lesi yang tidak dapat dilewati atau diperlebar dengan balon. Ke-32 penderita ini menjalani 72 tindakan, dimana rotablasi dan adjunctive atau complementary PTCA dilakukan pada 33 pembuluh darah untuk memperbaiki 50 lesi koroner. Lokasi lesi umumnya $(87,5 \%)$ pada pembuluh left anterior descending artery.Terdapat 19 lesi tipe B2 (38,0\%) dan 31 lesi tipe C $(62,0 \%)$. PTCA konvensional juga dilakukan pada 22 lesi. Dari ke-32 penderita tersebut, 19 pria dan 13 wanita. Umur berkisar 42 sampai 79 tahun. Kebanyakan mempunyai angina kelas CCS III atau IV. Fraksi ejeksi adalah $50 \%$ pada 17 penderita $(53,1 \%), 30-50 \%$ pada 10 penderita (31,3\%), dan $30 \%$ pada 5 penderita $(15,6 \%)$. Pada 3 penderita diperlukan pemasangan intra-aortic balloon pumping untuk stabilisasi hemodinamik. Tujuh penderita (21,9\%) mempunyai penyakit satu pembuluh, 19 (59,4\%) mempunyai penyakit dua pembuluh dan 6 (18,7\%) mempunyai penyakit tiga pembuluh. Angka keberhasilan angiografik dan proseduril $100 \%$. Hasil yang baik umumnya dicapai setelah dilakukan PTCA pasca rotablasi. Stenosis koroner yang kompleks dan tidak dapat di-dilatasi masih dapat diobati dengan rotablasi yang diikuti dengan PTCA.
\end{abstract}

\begin{abstract}
We studied 32 patients who had complex lesions or morphologic characteristics associated with poor outcome utilizing conventional PTCA, such as ostial stenosis, calcified lesions, long or diffuse lesions, restenotic lesions or lesions which can not be crossed or dilated with a balloon. These 32 patients underwent 72 procedures in which rotational atherectomy and adjunctive or complementary PTCA were performed in 33 vessels to treat 50 lesions. They were mainly $(87.5 \%)$ in the left anterior descending coronary artery. According to modified ACC/AHA lesion classification, there were 19 type B2 lesions (38.0\%) and 31 type C lesions (62.0\%). Plain balloon angioplasty was also performed in additional 22 lesions. Of the 32 patients, 19 were male and 13 female. Their ages ranged from 42 to 79 years. The majority presented with Canadian Cardiovascular Society angina class III or IV. The left ventricular ejection fraction was $50 \%$ in 17 patients $(53.1 \%), 30-50 \%$ in 10 patients $(31.3 \%)$ and $30 \%$ in 5 patients (15.6\%). In 3 patients rotational atherectomy was performed with the aid of intra-aortic balloon pumping for hemodynamic stabilization. Single vessel disease was present in 7 patients (21.9\%), double vessel disease in 19 patients (59.4\%) and triple vessel disease in 6 patients (18.7\%). Angiographic and procedural success rates were 100\%. However, largely, success criteria was achieved after adjunctive or complementary PTCA had been performed. Complex and "undilatable" coronary stenosis may be treated with rotational atherectomy and adjunctive or complementary PTCA.
\end{abstract}

Keywords : Coronary artery disease, angioplasty, atherectomy.

\section{INTRODUCTION}

Percutaneous transluminal coronary angioplasty (PTCA) in appropriately selected patients and performed by experienced operators has an overall procedural success that exceeds $90 \%$ with a complication

Division of Cardiology, Department of Internal Medicine, University of Indonesia Medical School/Dr. Cipto Mangunkusumo Hospital, Jakarta, Indonesia rate of less than $5 \% .^{1-4}$ However, there are many patient subgroups with difficult or complex morphology that are poor candidates for PTCA. Morphologic characteristics and circumstances associated with suboptimal results include: (a) ostial lesions, (b) significant calcification, (c) long, narrow or diffuse disease, (d) lesions crossable with wire, but no balloon could follow, and (e) lesions crossable with wire and balloon that do not yield to high pressures. Such lesions would ordinarily require coronary bypass surgery or they may even be so diffuse as to be inoperable. 
Rotational atherectomy is a technique that selectively ablates and pulverizes inelastic, fixed, atheromatous tissue into microparticles, which are smaller than red blood cells and freely pass through the capillaries. ${ }^{5,6}$ Compared to PTCA, the final result is an expanded, circular arterial lumen with a smooth, polished, less thrombogenic surface, which is free of significant dissection. ${ }^{5,6}$ The technique appears to be well suited for certain type B/ C lesions, such as ostial, calcified or long lesions and "undilatable lesions." Rotational atherectomy is not recommended for use in thrombus containing lesions, degenerated saphenous vein grafts and very long lesions (i.e. more than $25 \mathrm{~mm}$ in length). ${ }^{6}$ The use of rotational atherectomy as a stand alone device has been evaluated in several single and multicenter studies. ${ }^{7-9}$ Lower success and higher complication rates are noted, however, with increasing lesion complexity such as type $\mathrm{C}$ lesions and particularly in diffuse disease. ${ }^{6,10}$ The use of rotational atherectomy followed by PTCA has been performed with remarkable clinical success. ${ }^{6,7,9,10}$ The purpose of this study was to evaluate the efficacy and safety of this strategy in patients with complex and "undilatable" coronary lesions.

\section{MATERIALS AND METHODS}

\section{The Rotational Atherectomy Device (Rotablator)}

The Rotablator System (Heart Technology, Inc. Bellevue, WA) consists of a reusable console which controls and monitors the rotational speed of a disposable advancer. The advancer consists of an ellipticalshaped brass burr coated with 5 to $10 \mathrm{u}$ diamond chips bonded to a flexible drive shaft. It is powered with a comprised nitrogen-driven turbine that spins the burr over the guide wire at 160,000 to 190,000 revolutionsper-minute (rpm). Burr diameters range from 1.25 to $2.5 \mathrm{~mm}$. A $300 \mathrm{~cm}$ exchange length guide wire allows passage of sequentially increasing burr diameters over the same guide wire.

\section{Patients}

The study group consisted of 32 patients undergoing 33 rotational atherectomy procedures followed by balloon angioplasty. All patients had significant coronary artery disease with all lesions having $\geq 70 \%$ stenosis. All patients had complex lesions or morphologic characteristics associated with poor outcome utilizing conventional PTCA, such as ostial stenosis, calcified lesions, long or diffuse lesions, restenotic lesions or lesions which can not be crossed or dilated with a balloon. Patients with unprotected left main disease, visible thrombus or old degenerated vein grafts were excluded. In 3 patients with a left ventricular ejection fraction of $<30 \%$, intra-aortic balloon counter pulsation was applied for cardiac support while rotational atherectomy procedure was carried out.

\section{Procedure}

Pre-procedure medications included nitrates, calcium antagonist (unless contra-indicated), aspirin and ticlopidine. Procedural medications included heparin, intracoronary nitrates and verapamil. Ten thousand international units of heparin were given at the beginning of the procedure and then hourly as needed to keep the ACT > $350 \mathrm{msec}$. Liberal doses of intracoronary nitrates were utilized throughout the procedure to prevent coronary spasm. During right coronary or dominant left coronary rotational atherectomy, a temporary transvenous pacemaker was inserted prior to initiating the procedure.

A flexible 0.009 inch guide wire with a 0.017 inch spring tip was advanced though the guiding catheter across the lesion and positioned well distal in the target vessel. The rotating burr is slowly advanced over the guide wire and through the lesion while spinning at 16,000 to $190,000 \mathrm{rpm}$. Several passes were usually required until burr advancement was resistance free, each pass lasting 5 - 45 seconds depending on the lesion characteristics. We preferred to use smaller burr and upsized as necessary until adequate debulking was achieved. After rotational atherectomy, répeat angiography was performed and adjunctive PTCA was used to achieve a residual stenosis of less than $50 \%$.

An electrocardiogram was obtained before and after the procedure and repeated every day or when needed. Serum cardiac enzymes (creatine kinase -- CK and CK-MB) were measured 4 and 24 hours after atherectomy or until abnormal values returned to baseline.

\section{Definitions}

Angiographic success was defined as achievement of a final diameter stenosis of less than $50 \%$ and a decrease in diameter stenosis of $20 \%$ or more. Procedural success was defined as angiographically successful procedure in the absence of major complications, such as acute Q-wave myocardial infarction, emergency by-pass surgery or death. A Q-wave myocardial infarction was defined as the development of new Q-waves with serum enzymes elevated to twice normal levels. A non-Q wave myocardial infarction was defined as elevation of cardiac enzymes (CK, CK-MB) 
twice the normal values with no new Q-waves on the electrocardiogram. Non-Q wave myocardial infarction was not categorized as major complication, because clinically it did not appear to cause significant permanent sequel.

\section{RESULTS}

\section{Baseline characteristics}

Of the 32 patients, 19 were male and 13 female. Their ages ranged from 42 to 79 years (mean age $64 \pm 9$ years). The majority presented with Canadian Cardiovascular Society angina class III or IV. More than half had a history of hyperlipidemia. The left ventricular ejection fraction was $\geq 50 \%$ in 17 patients $(53.1 \%), 30-50 \%$ in 10 patients $(31.3 \%)$ and $<30 \%$ in 5 patients $(15.6 \%)$. In 3 of these 5 patients rotational atherectomy was performed with the aid of intra-aortic balloon pumping for hemodynamic stabilization (Table 1).

Single vessel disease was present in 7 patients (21.9\%), double vessel disease in 19 patients (59.4\%) and triple vessel disease in 6 patients $(18.7 \%$ ) (Table 2).

These 32 patients underwent 72 procedures in which rotational atherectomy and adjunctive or complementary PTCA were performed in 33 vessels to treat 50 lesions. They were mainly (87.5\%) in the left anterior descending coronary artery. According to modified ACC/AHA lesion classification, there were 19 type B2 lesions (38.0\%) and 31 type C lesions (62.0\%). Plain balloon angioplasty was also performed in additional 22 lesions (Tables 2 and 3).

The lesion length was more than $20 \mathrm{~mm}$ in 26 patients ( 31 lesions, or $81.2 \%$ ); the majority being on the third or more of the entire length of left anterior descending coronary artery course. Three patients had critical ostial left anterior descending coronary artery lesion, where adjunctive or complementary PTCA had to be performed with autoperfusion balloon catheters in which part of the balloon was in the left main stem, completely obstructing flow to the left circumflex coronary artery. Calcium was angiographically detectable in 47 lesions $(94.0 \%$ ) (Table 3).

\section{Outcome}

Angiographic success was achieved in all lesions $(100 \%)$ in which rotational atherectomy was used. However, largely, success criteria were met after adjunctive or complementary PTCA had been performed. Plain balloon angioplasty, performed to dilate non-atherectomized lesions were successful in all. Procedural success was also achieved in all patients (Table 4).

Six patients, 5 of whom had long and calcified lesion of more than $20 \mathrm{~mm}$, developed spasm. In 2 patients this led to complete vessel closure. However, in all cases spasm could be overcome after intracoronary nitrate administration and/or adjunctive PTCA. None of these 6 patients sustained an acute myocardial infarction.

Three patients had small intimal disruption (type B). Since such dissection was always benign, they were managed in manner similar to patients without dissection. In one patient with long, calcified lesion; adjunctive PTCA with a pressure of 5 atmospheres created a spiral luminal filling defect (type D) necessitating stent implantation. This later patient was discharged without complication. Two patients had dissection that led to impaired flow (type F). They were successfully managed with repeat balloon dilatation.

One patient with a long ( $20 \mathrm{~mm}$ ), calcified lesion in the left anterior descending coronary artery developed occlusion of big septal perforator and diagonal branches as well as a no-reflow phenomenon. A nonQ-wave anterior wall infarction and mild left heart failure ensued. The patient responded promptly and nicely to medical management. She remained asymptomatic at a follow-up period of 7 months. An echocardiogram performed at 6 months' follow-up revealed preserved left ventricular function and minimally hypokinetic regional wall motion in the area supplied by the reference artery. Three other patients showed a rise of cardiac enzymes to 2 times normal levels, but their electrocardiograms did not significantly change and their clinical course was uneventful.

There was no death and no patient required emergency bypass surgery (Table 4 ).

\section{DISCUSSION}

Although PTCA using conventional balloon technology is still the mainstay of interventional cardiology, in patients with complex anatomy or diffuse disease it is associated with a lower procedural success and higher complication rate. PTCA in type B2 and type C lesions has primary success rates as low as $76 \%$ and $61 \%$ and complication rates of $10 \%$ and $21 \%$, respectively. ${ }^{1,2}$ In more recent report the success rates were $89.5 \%$ and $90 \%$, respectively, for type B2 and type C lesions; as compared to $99 \%$ and $95 \%$, respectively, for type A and type B1 lesions. ${ }^{3}$ In our experience, we found success rates of $99.6 \% ; 98.7 \% ; 97.2 \%$ and 
Table 1. Clinical profile of 32 patients.

\begin{tabular}{lll}
\hline & No & $\%$ \\
\hline Gender & 19 & 59.4 \\
Age $(\mathbf{y r})(\mathbf{M} \pm$ SD, range) & $64 \pm 9,42-79$ & - \\
Diabetes & 11 & 34.4 \\
Hypertension & 13 & 40.6 \\
Hyperlipidemia & 24 & 75.0 \\
Cigarette smoking & 11 & 34.4 \\
Angina, CCS III-IV & 25 & 78.1 \\
Prior myocardial infarction & 15 & 46.9 \\
Prior coronary artery bypass & & \\
$\quad$ surgery & 1 & 3.1 \\
Prior PTCA & 3 & 9.4 \\
Ejection fraction (\%) & & \\
$\quad *>50$ & 17 & 33.1 \\
$\quad * 30-50$ & 10 & 15.6 \\
$*<30$ & $5 \%$ & \\
\hline
\end{tabular}

Table 2. Extent of disease and number of procedures performed.

\begin{tabular}{lrc}
\hline & No & $\%$ \\
\hline Extent & & \\
$\quad$ Single vessel disease & 7 & 21.9 \\
Double vessel disease & 19 & 59.4 \\
$\quad$ Triple vessel disease & 6 & 18.7 \\
Rotational atherectomy + PTCA & & \\
$\quad$ Number of vessels & 33 & 103.1 \\
$\quad$ Number of lesions & & 50 \\
Site & & \\
- left anterior descending artery & 28 & 87.5 \\
- left circumflex artery & 2 & 6.2 \\
$\quad$ - right coronary artery & 3 & 9.4 \\
Additional PTCA in other sites & 22 & - \\
\hline
\end{tabular}

Table 3. Morphology of 50 lesions (33 target vessels in 32 patients) treated with rotational atherectomy and PTCA

\begin{tabular}{lrr}
\hline & No & $\%$ \\
\hline Long lesion & & \\
$\quad-1 \mathrm{~cm}$ & 17 & 34 \\
$-1-2 \mathrm{~cm}$ & 2 & 4 \\
$\quad>2 \mathrm{~cm}$ & 31 & 62 \\
Calcified & 47 & 94 \\
Ostial (LAD) & 3 & 6 \\
Bifurcation & 22 & 44 \\
Irregularities & 22 & 44 \\
Eccentric & 50 & 100 \\
Moderate-to-severe tortuosity & 19 & 38 \\
Moderate-to-severe angulation & 2 & 4 \\
Modified ACC/AHA Class : & & \\
$\quad$ - B2 & 19 & 38 \\
$\quad$ - C & 31 & 62 \\
\hline
\end{tabular}

Table 4. Success and complications

\begin{tabular}{lcc}
\hline & No & $\%$ \\
\hline Success & & \\
$\quad$ - angiographic (per lesion) & 50 & 100 \\
$\quad$ - procedural (per patient) & 32 & 100 \\
Complications & & \\
- transient occlusive spasm & 6 & 18.7 \\
- dissection, type D & 1 & 3.1 \\
- dissection, type F & 2 & 6.2 \\
- no reflow phenomenon & 1 & 3.1 \\
- non-Q-wave infarction & 4 & 12.5 \\
- Q-wave-infarction & -- & -- \\
- Emergencybypass surgery & -- & -- \\
- Death & -- & -- \\
\hline
\end{tabular}

$83.2 \%$, respectively, for types $\mathrm{A}, \mathrm{B} 1, \mathrm{~B} 2$ and $\mathrm{C}$ lesions. $^{4}$

In the present study, a strategy of rotational atherectomy followed by PTCA was employed in type B2 lesions in $38 \%$ and in type $\mathrm{C}$ lesions in $62 \%$ of the patients. Despite these adverse morphologic characteristics, a high overall success rate of $100 \%$ was obtained. In the ERBAC study, which is a randomized study comparing procedural and angiographic results of excimer laser angioplasty, rotational atherectomy ānd PTCA in patients with native de-novo type B or C lesions suitable to all the three techniques, stand alone rotational atherectomy resulted in better procedural success $(93 \%)$ as compared with PTCA $(84 \%)$ and excimer laser angioplasty $(89 \%) .{ }^{10}$ Recently, the use of rotational atherectomy followed by PTCA at low inflation pressure has been increasingly demonstrated to provide better results as compared to stand alone procedure. Although the debulking effect is less substantial, the angiographic results that can be obtained are more remarkable, particularly in long segmental stenosis with diffuse atheroma. ${ }^{6,7,9}$ The term "complementary angioplasty" is used if the balloon is inflated at a very low pressure ( 0.5 to $2.5 \mathrm{~atm})$ after rotational atherectomy to relieve vasospasm or to smoothen a satisfactorily atherectomized segment. The term "adjunctive angioplasty" denotes a procedure in which a balloon is used at normal or high pressure after rotational atherectomy. In this instance the balloon is used to salvage the rotational atherectomy, e.g. because of no-reflow phenomenon or significant dissection resulting in abrupt vessel closure. ${ }^{7}$ Our result was similar to the success rates reported in previous investigations, which also included type $A$ and type $B$ lesions. ${ }^{7,9,10}$ In these reports, adjunctive or com- 
plementary PTCA was also performed in the majority ${ }^{7,9}$ or all cases. ${ }^{8}$

In our study, salvage PTCA to treat no-reflow phenomenon was done in one patient. The peak balloon pressure that was applied was $5 \mathrm{~atm}$. In 2 other patients with abrupt vessel closure because of vasospasm, beside-intracoronary nitrates, balloon angioplasty was performed at a peak inflation pressure of 4 - 5 atm. In the rest of the patients, PTCA was used to optimize the result of rotational atherectomy. Although we tried to use low pressures, 9 patients had their balloons inflated to higher pressures of $6-10 \mathrm{~atm}$. In these patients the rotational atherectomy might have not been enough to debulk the calcified lesions.

In conclusion, the present study suggests that complex and "undilatable" coronary stenosis may be treated with rotational atherectomy and adjunctive or complementary PTCA. Further investigations are required to confirm our findings.

\section{REFERENCES}

1. Detre K, Holubkov R, Kelsy S, et al. One-year follow-up results of the 1985-1986 National Heart, Lung, and Blood Institute's Percutaneous Transluminal Coronary Angioplasty Registry. Circulation 1989;80:421-428

2. Bentivoglio LG, Holubkov R, Kelsey SF, et al. Short and long term outcome of percutaneous transluminal coronary angioplasty in unstable versus stable angina pectoris : A report of the 1985-1986 NHLBI PTCA Registry. Cathet Cardiovasc Diagn 1991;23:227-238

3. Myler RK, Shaw RE, Stertzer SH, et al. Lesion morphology and coronary angioplasty : Current experience and analysis. J Am Coll Cardiol 1992;19:1641-1652

4. Santoso T, et al. Lesion morphology and PTCA. Is $A B C$ classification obsolete? (abstr.).Asean Federation Congress of Cardiology, Bangkok, 1994, p 260

5. Farb A, Roberts DK, Pichard A, et al. Coronary artery morphologic features after coronary rotational atherectomy : Insights into mechanisms of lumen enlargement and embolization. Amer Heart J 1995;129:1058-1067

6. Reisman M. Guide to rotational atherectomy. Physician's Press : Birmingham, 1997.

7. Stertzer SH, Pomerantsev EV, Shaw RE, et al. Comparative study of the angiographic morphology of coronary artery lesions treated with PTCA, directional coronary atherectomy or high speed rotational ablation. Cathet Cardiovasc Diagn 1994;33:1-9

8. Sabri MN, Cowley MJ, DiSciasco G, et al. Immediate results of interventional devices for coronary ostial narrowing with angina pectoris. Am J Cardiol 1994;73:122-125

9. Borrione M, Hall P, Almagor Y, et al. Treatment of simple and complex coronary stenosis using rotational ablation followed by low pressure balloon angioplasty. Cathet Cardiovase Diagn 1993;30:131-137.

10. Vandormael M, Reifart N, Preusler W, et al. Comparison of excimer laser, rotablator and balloon angioplasty for the treatment of complex lesions : ERBAC study final results (abst.) J Am Coll Cardiol 1994;23:57A. 